\title{
Comment on "Estimating the depth and evolution of intrusions at resurgent calderas: Los Humeros (Mexico)" by Urbani et al. (2020)
}

\author{
Gianluca Norini and Gianluca Groppelli \\ Istituto di Geologia Ambientale e Geoingegneria, Sezione di Milano, Consiglio Nazionale delle Ricerche, Italy \\ Correspondence: Gianluca Norini (gianluca.norini@cnr.it)
}

\begin{abstract}
A multiple magmatic intrusions model has been proposed by Urbani et al. (2020) for the resurgence of the Los Potreros caldera floor, in the Los Humeros Volcanic Complex. This model predicts (1) the occurrence of few localized bulges in the otherwise not deformed caldera floor, and (2) that the faults corresponding to different bulges exhibit different spatial and temporal evolution. Already available field data from easily accessible outcrops and a simple morphological analysis show that these two conditions are not met at Los Potreros caldera. Also, a geothermal well $(\mathrm{H} 4)$, located in the most recent supposed bulge for which Urbani et al. (2020) calculated an intrusion depth (Loma Blanca, intrusion depth of $425 \pm 170 \mathrm{~m}$ ), doesn't show any thermal and lithological evidence of such a shallow cryptodome. Finally, already published stratigraphic data and radiometric dating apparently disprove the proposed correlation between extruded viscous lavas and faulting. Thus, even if recent shallow intrusions may exist in the area, Urbani et al. (2020) fails to provide any useful information on their occurrence, location, age, emplacement depth, role in the resurgence of the Los Potreros caldera floor, and influence on the structure of the Los Humeros geothermal field.
\end{abstract}

\section{Introduction}

Urbani et al. (2020) (henceforth U2020) made a contribution to the study of caldera resurgence based on field data and geothermal well logs from the Los Humeros Volcanic Complex (LHVC) and scaled analogue models. U2020 constrained the spatial-temporal evolution of post-caldera volcanism at LHVC and estimate the depth of the magmatic intrusions feeding the active geothermal system by integrating the fieldwork data, well logs and laboratory results.

The main conclusion of U2020 is that the resurgence of the Los Potreros caldera in the LHVC "is due to multiple deformation sources", "linked to small magmatic intrusions located at relatively shallow depths (i.e. < $1 \mathrm{~km}$ )". U2020 suggested that these intrusions should be located below three uplifted areas surrounding the Arroyo Grande, Los Humeros and Loma Blanca faults, respectively.

The analysis by U2020 suffers from poor field data (Section 2), geometric and structural inconsistencies between the LHVC post-caldera deformation and the analogue modelling (Section 3), lack of any substantial validation of the results with the available well logs (Section 4), and contradictions with the reference stratigraphy and radiometric ages recently published by some of the U2020 authors (Section 5). These problems, which largely undermine their conclusions, are discussed below.

\section{Location and relative age of faulting}

The occurrence and relative age of faulting is analysed by U2020 observing faults and hydrothermal alteration in the Holocene Cuicuiltic Member unit (Dávila-Harris and Carrasco-Núñez, 2014). The Cuicuiltic Member blankets the whole area, is very well exposed, has been dated at ca. $7 \mathrm{ka}$ and is made of alternated fallout 
deposits of different composition and colour (Dávila-Harris and Carrasco-Núñez, 2014). The Cuicuiltic Member has been considered an ideal marker layer for documenting Holocene faulting and stratigraphy in the caldera complex, because of the contrasting black and white colours of the alternated fallout deposits composing the unit (e.g. Dávila-Harris and Carrasco-Núñez, 2014; Norini et al., 2015, 2019; U2020). This unique feature makes the Cuicuiltic Member easily recognizable in the field, and any displacement along faults very sharp and pristine (Dávila-Harris and Carrasco-Núñez, 2014). Indeed, many easily accessible outcrops showing faults in the Cuicuiltic Member have been documented within the Los Potreros caldera by Dávila-Harris and Carrasco-Núñez (2014), Norini et al. (2015, 2019) and GEMex (2019) (Figs. 1 and 2).

51

U2020 proposed a new interpretation of some structures already identified in previous studies (e.g. Arellano et al., 2003; Norini et al., 2015, 2019). The reinterpretation of U2020 has been based on their field data, distinguishing between lineaments ("morphological linear scarps with no measurable fault offsets and/or alteration at the outcrop scale") and active and inactive faults ("associated with measurable fault offsets and with active or fossil alteration"), respectively. The reinterpreted structural features are the Las Papas, Las Viboras, Arroyo Grande and Maxtaloya faults (Fig. 1).

U2020 concluded that the Las Papas and Las Viboras are "morphological scarps" and "lineaments" not related with faulting. For the Las Papas lineament, U2020 stated that "unaltered and undeformed deposits of the Cuicuiltic Member crop out along the E-W Las Papas lineament" and that it "is probably due to differential erosion of the softer layers of the pyroclastic deposits". Even if the Las Papas and Las Viboras structures are several km long, the statements by $\mathrm{U} 2020$ have only been based on a single outcrop on the Las Papas trace (their $\mathrm{LH}-08$, while their $\mathrm{LH}-07$ outcrop is out of the fault trace, see fig. 3C). Several easily accessible outcrops had been previously found along the Las Papas and Las Viboras faults, as well as along many other faults deforming the area surrounding these two main volcanotectonic structures (Fig. 1) (e.g. Dávila-Harris and Carrasco-Núñez, 2014; Norini et al., 2015, 2019; GEMex, 2019). In all these outcrops, the faults invariably displace the Holocene Cuicuiltic Member and the underlying lava and pyroclastic units (for example see outcrops LH2017_32, LH64, LH62, LH66, LH23 in figs. 1 and 2). This means that the U2020 conclusion that the Las Papas and Las Viboras are not faults is obviously wrong, as shown by many already available data, and as also easily verifiable with a short field survey (Figs. 1 and 2) (e.g. Dávila-Harris and Carrasco-Núñez, 2014; Norini et al., 2015, 2019; GEMex, 2019). The U2020 description of their LH-08 outcrop can be explained by erosive retreat of the fault scarp, a very common process in dip-slip faults, especially in poorly consolidated sediments (e.g. Keller and Pinter, 2002; Burbank and Anderson, 2011). These observations show that previous works correctly concluded that Las Papas and Las Viboras are faults and have been active in the Holocene (e.g. Cedillo, 1997; Arellano et al., 2003; Dávila-Harris and Carrasco-Núñez, 2014; Norini et al., 2015, 2019; Carrasco-Núñez et al., 2017; GEMex, 2019).

U2020 inferred that the Arroyo Grande and Maxtaloya scarps have been generated by nowadays inactive faults. U2020 stated that these faults have been active "prior to the deposition of the Cuicuiltic Member". The statement by $\mathrm{U} 2020$ arose from the analysis of two outcrops (their $\mathrm{LH}-09$, see fig. 3C, and the H6 well pad), where "strongly altered and faulted ... lavas and ignimbrites" are "covered by the unaltered Cuicuiltic Member". As well known, active/fossil alteration doesn't always allow identifying faults or the age of faulting, because it depends also on their depth, life span of the hydrothermal system, spatial relationships, and fluid paths along primary permeability and faults zones (Bonali et al., 2016; Giordano et al., 2016). Easily accessible outcrops of the Arroyo Grande and Maxtaloya faults show displacements of the Cuicuiltic Member, clearly indicating that the conclusions of U2020 about the age of these two structures and the correlation between faulting and hydrothermal alteration are wrong (for example see outcrops PDL52, LH20, PDL08 in figs. 1 and 2) (Norini et al., 2015, 2019; GEMex, 2019). Faults displacing the Cuicuiltic Member are clearly exposed along 
the Maxtaloya fault in the $\mathrm{H} 6$ geothermal well pad (corresponding to the PDL08 outcrop of figs. 1 and 2H). The Maxtaloya fault trace is also coincident with a sharp thermal anomaly identified by Norini et al. (2015). U2020 didn't mention this thermal anomaly, which further undermines their hypothesis and conclusions, when they used the thermal remote sensing results of Norini et al. (2015) (Section 5.3 in U2020). Well documented Holocene faulting (e.g. figs. 1 and 2) indicates that the Arroyo Grande and Maxtaloya faults have been active after the deposition of the Cuicuiltic Member. Also, a sharp thermal anomaly suggests that the Maxtaloya fault plays nowadays an important role in the ascent of hot geothermal fluids (Norini et al., 2015, 2019; Carrasco-Núñez et al., 2017; GEMex, 2019).

\section{Identification and geometry of uplifted areas}

U2020 identified three "main uplifted areas" surrounding the surface expressions of the Loma Blanca, Arroyo Grande and Los Humeros faults. The supposed uplifted area around the Loma Blanca fault has also been named by U2020 "Loma Blanca bulge". Regrettably, U2020 didn't provide any information on how these uplifted areas have been identified and delimited. Among the three supposed uplifted areas, only the bulge corresponding to the Loma Blanca fault has been briefly described: "The fault system is on top of an elongated crest (within an apical depression) of a morphological bulge, $1 \mathrm{~km}$ in width and $30 \mathrm{~m}$ in height". Conversely, no description or morphological data about the Arroyo Grande and Los Humeros uplifted areas have been provided in U2020.

Simple topographic profiles of the caldera floor clearly show that these "uplifted areas" (or "bulges") have been arbitrarily defined, without any specific and reproducible criterion (Fig. 3). The identification of apical depressions by U2020 seems to be equally arbitrary. The "uplifted areas" include asymmetric reliefs and depressed sectors, and have boundaries not necessarily corresponding to slope changes useful for their delimitation (Fig. 3). The "Loma Blanca bulge" defined by U2020 comprises a sector of a westward tilted and faulted surface, already described by Norini et al. (2019). The western boundary of the supposed "bulge" is in the middle of the tilted surface, while the eastern one, corresponding to an already mapped normal fault, is nearly at the same elevation of the summit of the "bulge" (Figs. 1 and 3A-3C) (Carrasco-Núñez et al., 2017; Norini et al., 2019). Similarly, the eastern and western boundaries of the Arroyo Grande and Los Humeros "uplifted areas" have been located by U2020 in the middle of tilted or flat surfaces, without any discernible criterion (Fig. 3).

The $\mathrm{U} 2020$ model predicts the formation of an apical depression on top of a bulge induced by a shallow magmatic intrusion. As clearly shown in the cross-sections of their figure 10, U2020 depicted apical depressions on top of the three "uplifted areas" of Loma Blanca, Arroyo Grande and Los Humeros. Unfortunately, topography doesn't show any well-defined apical depression in the Arroyo Grande and Los Humeros areas (Fig. 3A-B). In fact, U2020 haven't even attempted to provide any description of those apical depressions. Thus, the Arroyo Grande and Los Humeros apical depressions drawn in their figure 10 don't have any relation with the topography and the structure of the caldera floor (e.g. Figs. 1 and 3 of the present comment and fig. 4 of U2020).

Along with wrong interpretation of faults in the field and questionable delimitation of "uplifted areas" and "apical depressions", U2020 also fails providing any kind of significant/independent validation of their multiple magmatic intrusion model. For example, the U2020 analogue modelling predicts the development of reverse faults at the base of the "bulges" induced by the emplacement of shallow cryptodomes (e.g. fig. 7 in U2020). U2020 didn't provide any field data or other evidence (morphostructural interpretation, geophysics, well logs, etc.) locating these reverse faults, which are a fundamental feature of their model. As 
noted above, the "Loma Blanca bulge" is delimited to the east by a normal fault already mapped by previous authors (Carrasco-Núñez et al., 2017; Norini et al., 2019). This means that the modelling results cannot be independently validated, as also discussed in the next section.

\section{Validation of the proposed model with well logs}

One of the most significant findings of U2020 is that the uplift in the "Loma Blanca bulge" has been generated by a magmatic intrusion located at $425 \pm 170 \mathrm{~m}$ of depth. U2020 also stated that this is the heat source of the local geothermal anomaly. Such a shallow depth is within the range of geothermal wells drilled in the area. Thus, the analysis of well logs might provide an opportunity to test the U2020 hypothesis and calculation of intrusion depth. In fact, a simple validation attempt of the U2020 model in the "Loma Blanca bulge" consists in the comparison of the temperature and lithological $\mathrm{H} 4$ well logs with the predicted intrusion depth. This well is located on the top of the "bulge", just to the west of its "apical depression" (Fig. 3C-3D). Thus, the well logs should show a significant temperature change and intrusive/sub-volcanic lithologies at the magma emplacement depth calculated by U2020.

According to data published by Arellano et al. (2003) and U2020, the H4 stratigraphic log doesn't show any evidence of intrusive bodies from the surface down to $1900 \mathrm{~m}$ of depth, nor a sharp increase of the temperature and geothermal gradient, which remains constant (about $20^{\circ} \mathrm{C} / 100 \mathrm{~m}$ ) (fig. $3 \mathrm{D}$ ). Also, the temperature profiles measured in several wells of the field, as displayed in the fig. 17 of Arellano et al. (2003), don't show any strong temperature inversion or sharp changes in the geothermal gradient possibly correlated to recent intrusive bodies at very shallow depth (" $<1 \mathrm{~km}$ "). On the contrary, these data indicate a deeper origin of the heat source (or sources), with some variation of the geothermal gradient due to faults and or permeability changes.

\section{Stratigraphy and radiometric ages}

One of the results presented in U2020 is that "...the recent (post-caldera collapse) uplift in the Los Potreros caldera moved progressively northwards ... along the Los Humeros and Loma Blanca scarps". Based on the proposed U2020 uplift model, it means that shallow intrusions of small magmatic bodies and, consequently, the volcanic feeding system moved progressively northwards. This statement presents some discrepancies with the stratigraphy, geology and radiometric ages recently published by some of the U2020 authors (Carrasco-Núñez et al., 2017, 2018; Juárez-Arriaga et al., 2018), as summarised by the following points:

a) An obsidian dome (Qr1 Rhyolite of Carrasco-Núñez et al., 2017) has been dated using the U/Th method at $44.8 \pm 1.7$ ka by Carrasco-Núñez et al. $(2017,2018)$. Its location corresponds to the obsidian dome cropping out along the Los Humeros fault described in U2020 and connected with the syn- to post-Cuicuiltic Member eruption (7.3-3.8 ka) (Fig. 4). In U2020 there is no description of two generations of obsidian domes along Los Humeros fault, nor any explanation to invalidate the previous radiometric dating. Therefore, the U2020 attribution of this obsidian dome to the 7.3-3.8 ka volcanic activity phase appears unjustified and, consequently, weakens their model;

b) The most recent volcanic activity of LHVC (post-Cuicuiltic Member) is clustered in two main ages, around 3.8 and $2.8 \mathrm{ka}$, as indicated by recent radiometric and paleomagnetic data (Carrasco-Núñez et al., 2017; Juárez-Arriaga et al., 2018) (Fig. 4). According to these ages and the LHVC geological map (Carrasco-Núñez et al., 2017), the vents feeding the post-Cuicuiltic Member volcanic activity are mainly located close to the southern and south-western sectors of the Los Humeros caldera rim. 
These data suggest that the shallow feeding system of the post-Cuicuiltic Member activity is mainly located in the southern and south-western sectors of the LHVC, some kilometres far from the supposed bulged areas. Also, the ages and locations of the volcanic vents do not show any progressive northward shift, but a scattered activity along the Los Humeros caldera rim.

\section{Conclusion}

We identified several problems in the U2020 study, showing that their model does not conform to most of the, if not all, geological constraints from the Los Potreros caldera. The boundary conditions of a model and the validation of the modelling results should always be based on the geological constraints that the natural prototype imposes. Conversely, the multiple magmatic intrusion model is imposed by U2020 to the natural prototype regardless of several evidences of no fit between them. This mismatch between nature and model includes the age and location of faulting, identification and delimitation of uplifted areas and apical depressions, temperature and lithological well logs, and stratigraphic and radiometric data. The forced application of a predetermined model to a natural prototype raises questions about the real purpose of this kind of studies. Such modelling could even be counterproductive for scientific knowledge if applied to case studies for which there are few geological constraints (for example in remote areas), and therefore an independent validation of the results is more difficult or impossible. Fortunately, previous recent studies provided enough independent data to validate new models applied to the LHVC. The occurrence of multiple magmatic intrusions at different depths in the Los Potreros caldera is not questioned in our comment, but we think that the U2020 study fails to identify the deformation source (or sources) driving caldera resurgence and representing the heat source of the geothermal field. As a result, their calculations and conclusions are unlikely to have any relevance to volcanotectonic or geothermal processes in the LHVC.

Data availability: all the data presented in this paper are available upon request.

Author contributions: Gianluca Norini and Gianluca Groppelli are equally responsible for Conceptualization (research planning), Investigation (field analysis, geomorphological analysis, review of well logs and stratigraphic data), Writing - Original Draft and Review \& Editing, and Visualization (figures and maps).

Competing interests: the authors declare that they have no conflict of interest.

\section{Acknowledgments}

The research leading to these results has received funding from the GEMex Project, funded by the European Union's Horizon 2020 research and innovation programme under grant agreement No. 727550.

\section{References}

Arellano, V.M., Garcia, A., Barragan, R.M., Izquierdo, G., Aragon, A., Nieva, D., 2003. An updated conceptual model of the Los Humeros geothermal reservoir (Mexico). J. Volcanol. Geotherm. Res. 124, 67-88.

Bonali, F., Corazzato, C., Bellotti, F., and Groppelli, G. (2015). Active tectonics and its interactions with Copahue volcano. In F. Tassi, O. Vaselli, \& A.T. Caselli (eds.), Copahue Volcano, Springer, Berlin Heidelberg, 23-45. 
https://doi.org/10.5194/se-2020-110

Preprint. Discussion started: 1 July 2020

(c) Author(s) 2020. CC BY 4.0 License.

Burbank D.W. and Anderson R.S. (2011). Tectonic Geomorphology. Second Edition, John Wiley \& Sons, Ltd, Chichester, UK. 274 pp.

Carrasco-Núñez, G., Hernández, J., De León, L., Dávila, P., Norini, G., Bernal, J.P., Jicha, B., Navarro, M., LópezQuiroz, P., and Digitalis, T.: Geologic Map of Los Humeros volcanic complex and geothermal field, eastern Trans-Mexican Volcanic Belt, Terra Digitalis, https://doi.org/10.22201/igg.terradigitalis.2017.2.24.78, 2017.

Carrasco-Núñez, G., Bernal, J. P., Davila, P., Jicha, B., Giordano, G., and Hernández, J.: Reappraisal of Los Humeros volcanic complex by new U/Th zircon and 40Ar/39Ar dating: Implications for greater geothermal potential, Geochem. Geophy. Geosy., 19, 132-149, 2018.

Cedillo, F., 1997. Geologia del subsuelo del campo geotermico de Los Humeros, Pue. Internal Report HU/RE/03/97, Comision Federal de Electricidad, Gerencia de Proyectos Geotermoelectricos, Residencia Los Humeros, Puebla, $30 \mathrm{pp}$.

Dávila-Harris, P. and Carrasco-Núñez, G.: An unusual syn-eruptive bimodal eruption: The Holocene Cuicuiltic Member at Los Humeros caldera, Mexico, J. Volcanol. Geoth. Res., 271, 24-42, https://doi.org/10.1016/j.jvolgeores.2013.11.020, 2014.

GEMex (2019). Final report on active systems: Los Humeros and Acoculco. Deliverable 4.1. GEMex project technical report, Horizon 2020, European Union, 334 pp. www.gemex-h2020.eu.

Giordano G., Ahumada F., Aldega L., Baez W., Becchio R., Bigi S., Caricchi C., Chiodi A., Corrado S., De Benedetti A., Favetto A., Filipovich R., Fusari A., Groppelli G., Invernizzi C., Maffucci R., Norini G., Pinton A., Pomposiello C., Tassi F., Taviani S., Viramonte J. (2016). Preliminary data on the structure and potential of the Tocomar geothermal field (Puna plateau, Argentina). Energy Procedia, 97, 202-209.

Juárez-Arriaga, E., Böhnel, H., Carrasco-Núñez, G., Nasser Mahgoub, A. (2018). Paleomagnetism of Holocene lava flows from Los Humeros caldera, eastern Mexico: Discrimination of volcanic eruptions and their age dating. Journal of South American Earth Sciences, 88, 736-748.

Keller, E.A. and Pinter, N. (2002). Active Tectonics: Earthquakes, Uplift, and Landscape. Second Edition. Prentice Hall, Upper Saddle River, 361 pp.

Norini, G., Groppelli, G., Sulpizio, R., Carrasco-Núñez, G., Dávila-Harris, P., Pellicioli, C., Zucca, F., and De Franco, R.: Structural analysis and thermal remote sensing of the Los Humeros Volcanic Complex: Implications for volcano structure and geothermal exploration, J. Volcanol. Geoth. Res., 301, 221-237, https://doi.org/10.1016/j.jvolgeores.2015.05.014, 2015.

Norini, G., Carrasco-Núñez, G., Corbo-Camargo, F., Lermo, J., Hernández Rojas, J., Castro, C., Bonini, M., Montanari, D., Corti, G., Moratti, G., Chavez, G., Ramirez, M., and Cedillo, F.: The structural architecture of the Los Humeros volcanic complex and geothermal field, J. Volcanol. Geoth. Res., 381, 312-329, https://doi.org/10.1016/j.jvolgeores.2019.06.010, 2019.

Urbani, S., Giordano, G., Lucci, F., Rossetti, F., Acocella, V., and Carrasco-Núñez, G.: Estimating the depth and evolution of intrusions at resurgent calderas: Los Humeros (Mexico), Solid Earth, 11, 527-545, https://doi.org/10.5194/se-11-527-2020, 2020. 
https://doi.org/10.5194/se-2020-110

Preprint. Discussion started: 1 July 2020

(c) Author(s) 2020. CC BY 4.0 License.

Figure Captions

250 Figure 1: volcanotectonic map of the Los Potreros caldera area, on a DEM (illuminated from the E) (modified 251 from GEMex, 2019 and Norini et al., 2019). Las V.F.: Las Viboras fault; Arroyo G.F.: Arroyo Grande fault; Loma 252 B.F.: Loma Blanca fault. Location of outcrops in fig. 2 is shown. Traces of A-A'-A"-A'"' and B-B' topographic 253 profiles of fig. 3 are also shown.

Figure 2: photographs of faults in the Cuicuiltic Member exposed by outcrops along the structures mapped in fig. 1.

Figure 3: topographic profiles along the (A) $A-A^{\prime}-A^{\prime \prime}-A^{\prime \prime \prime}$ and (B) $B-B^{\prime}$ traces shown in fig. 1, and (C) schematic geological map (modified from U2020) outlining the three uplifted areas discussed by U2020; the traces of the two topographic profiles and the locations of the $\mathrm{H} 4$ and $\mathrm{H} 20$ well are also shown. (D) $\mathrm{H} 4$ lithological and temperature logs (well data from Arellano et al., 2003, and U2020). P.c.: Post-caldera group.

Figure 4: map of the post-Cuicuiltic Member vents and ages based on radiometric data, paleomagnetic analysis or inferred from geological map (Carrasco-Núñez et al., 2017, 2018; Juárez-Arriaga et al., 2018). The post-Cuicuiltic Member uplifted areas and obsidian dome proposed by U2020 are also shown. Active faults are from Norini et al. (2019). 
https://doi.org/10.5194/se-2020-110

Preprint. Discussion started: 1 July 2020

(c) Author(s) 2020. CC BY 4.0 License.

Figure 1:

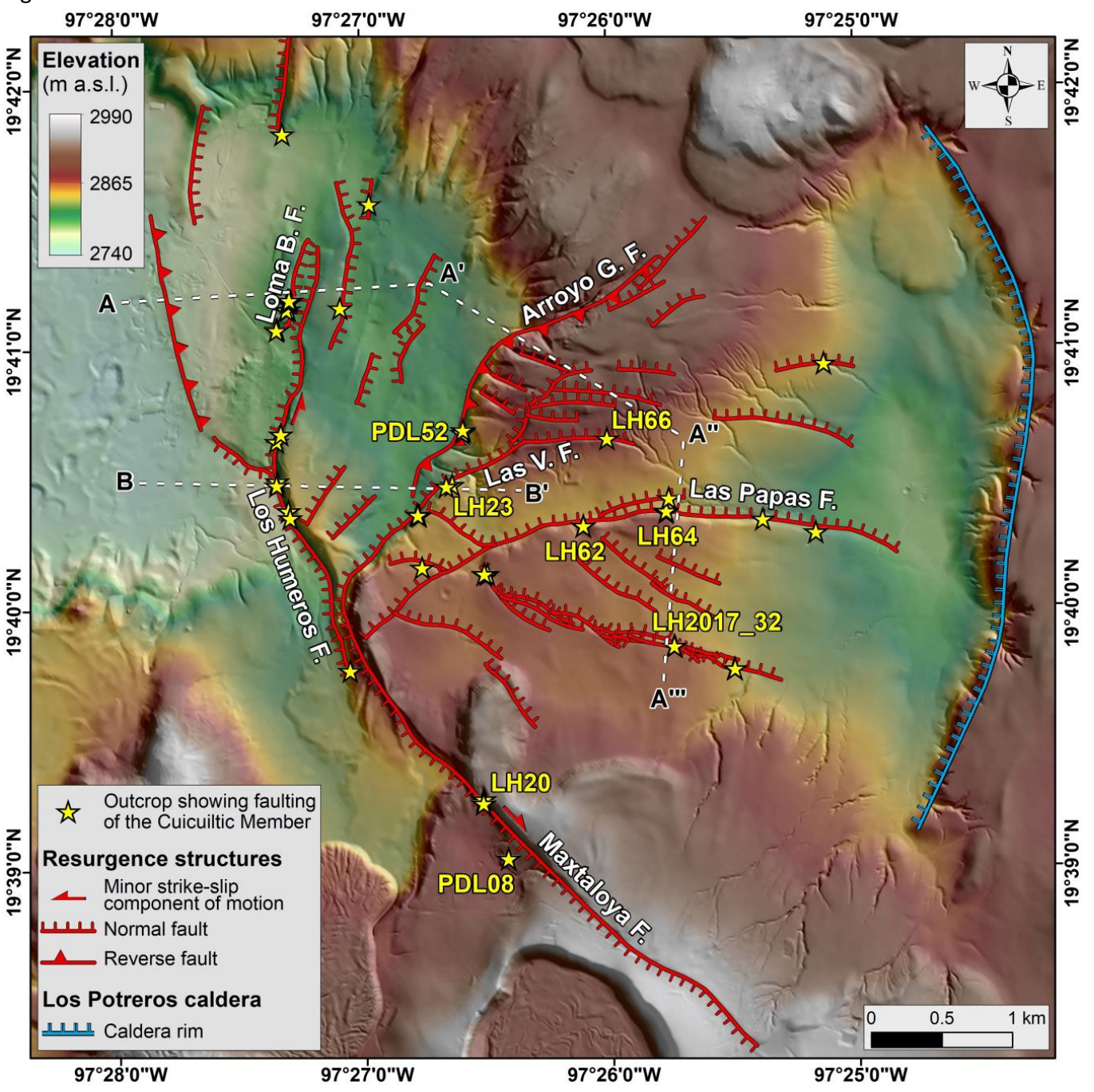


https://doi.org/10.5194/se-2020-110

Preprint. Discussion started: 1 July 2020

(c) Author(s) 2020. CC BY 4.0 License.

(c) (i)
268 Figure 2:
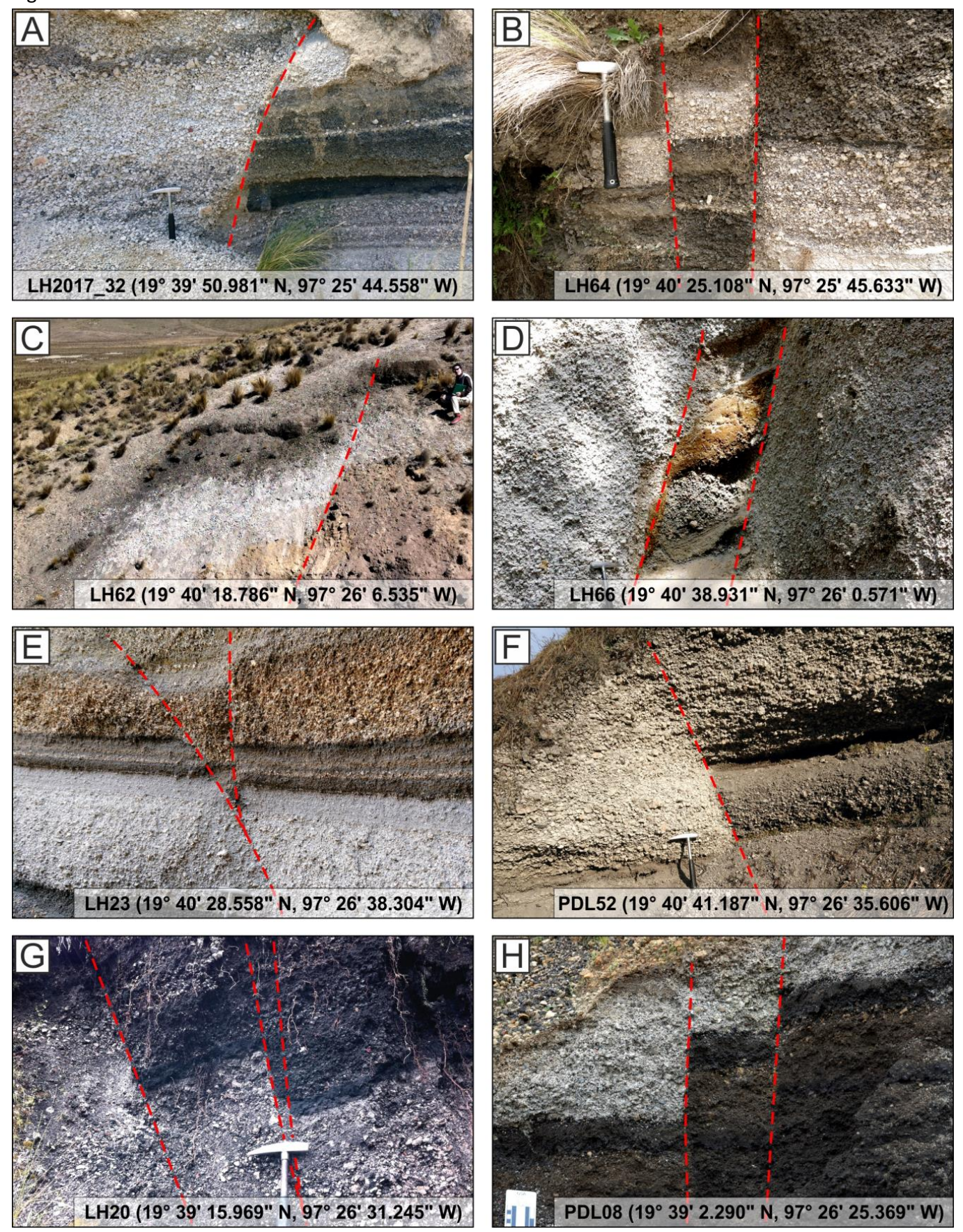

270 
https://doi.org/10.5194/se-2020-110

Preprint. Discussion started: 1 July 2020
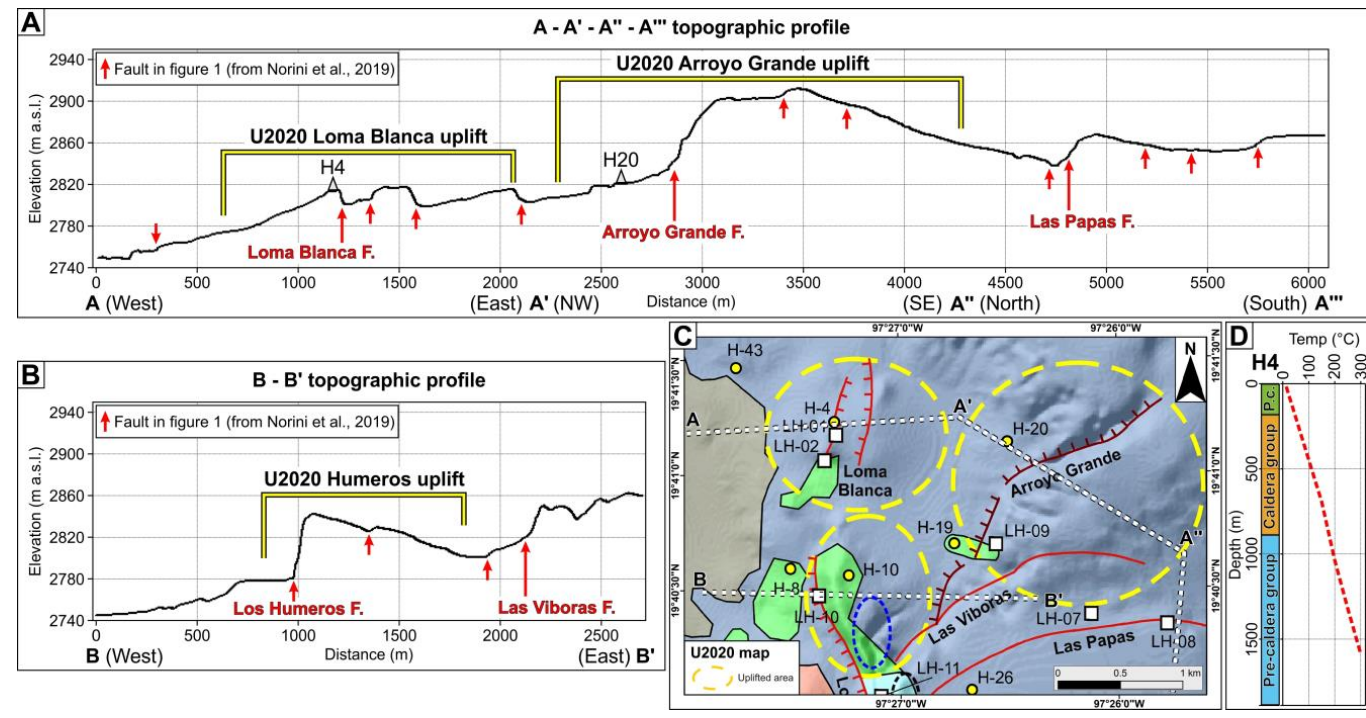

273 Figure 4:

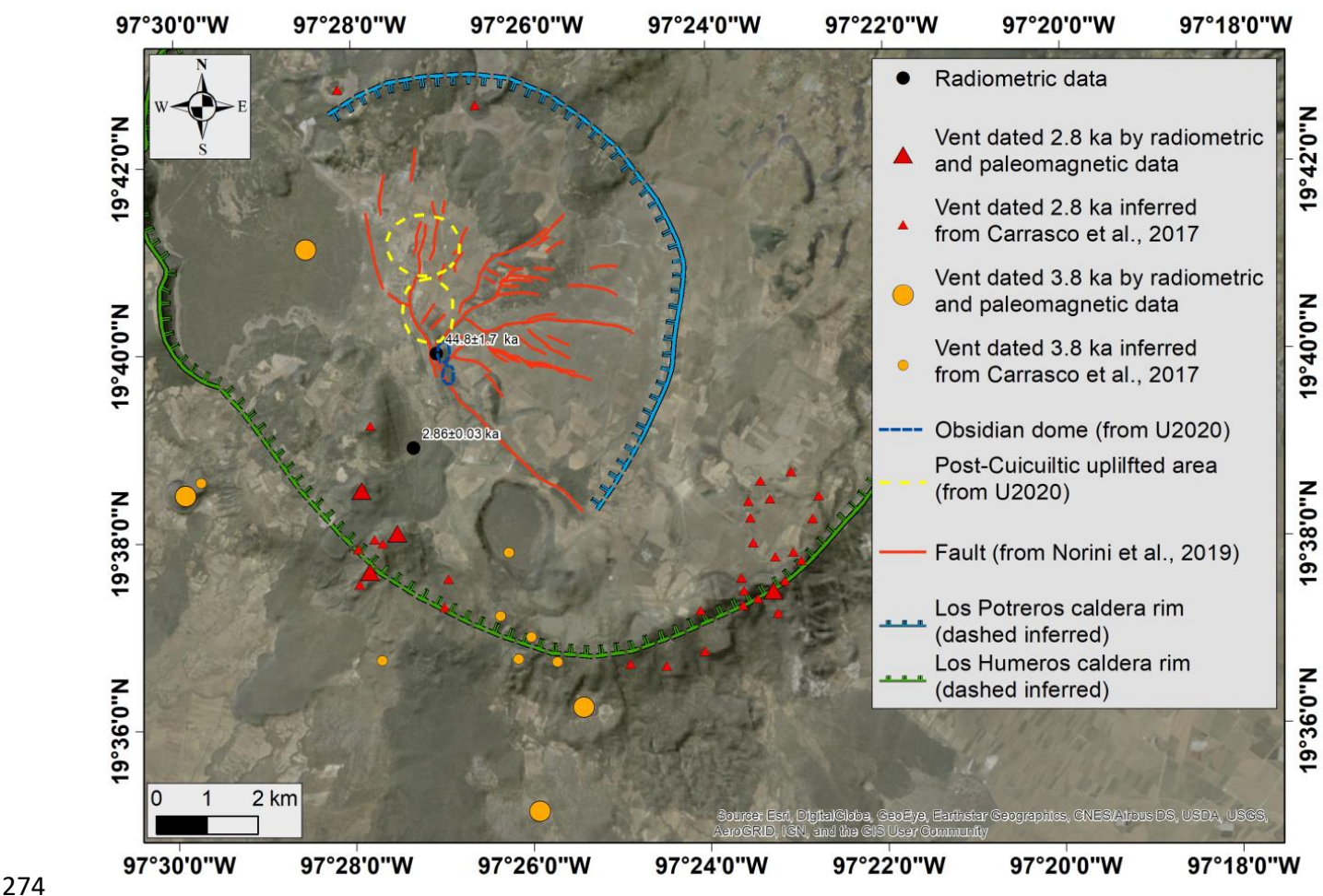

